\begin{tabular}{lccr} 
T H E A R C H I V E & O F & M E C H A N I C A L & E N G I N E E R I N G \\
\hline VOL. LX & 2013 & Number 2 \\
10.2478/meceng-2013-0013 & & \\
Key words: F-duct, forced separation &
\end{tabular}

PAULINA PIETRZAK, JANUSZ PIECHNA*

\title{
NUMERICAL INVESTIGATION OF THE CONTROLLABLE WING STALL CAUSED BY THE AIR INJECTION
}

\begin{abstract}
This paper presents results of numerical investigation on a controllable airfoil flow separation phenomena practically applied in Formula One racing by a device called the F-duct. Separation is forced by air jets from slots located at different positions on the profile of the dual element wing and is intended to reduce aerodynamic drag. Slot position and the air jet velocity are the main parameters controlling the flow separation. The flow structure, surface pressure distribution, and the generated downwards lift and drag forces were investigated in this study. Two different flow separation structures have been recognised. Typically, wing stall is correlated with an increase in aerodynamic drag force. However, in the case of the finite wing with low aspect ratio, the induced drag is dominant and is proportional to the downforce. Therefore, flow separation on the wing increases the profile drag while simultaneously reducing the induced drag, resulting in a decrease in the total aerodynamic drag.
\end{abstract}

\section{Introduction}

Wings are the typical elements used in racing cars for aerodynamic downwards lift generation. The rear wing produces about $35 \%$ of the total aerodynamic downforce of a car, which enhances the dynamic handling and stability, although at the same time, it generates $30 \%$ of the total aerodynamic drag [1]. As a consequence, a compromise must be found between the maximum cornering speed, which is greatly influenced by the negative lift force, and the reduction of the racing car's top speed due to drag generation.

There are about 20 active Formula One racetracks in the world, each of them requiring specific aerodynamic settings according to the diverse tracks characteristics. For instance, as shown in Figure 1, the Monza course has long straights and fast corners, and therefore requires minimal downforce

* Warsaw University of Technology, The Faculty of Power and Aeronautical Engineering, 00-665 Warsaw, Nowowiejska 24; E-mail: jpie@meil.pw.edu.pl 
that in turn leads to lower drag and, consequently, higher top speed. On the other hand, Circuit de Monaco, allocated to the city streets, has tight corners which require a high aerodynamic downforce in order to maximise the grip of the tyres. Therefore, in order to avoid prominent aerodynamic drag on the straight section of the racetrack, a very eligible solution would be the use of a movable rear wing.
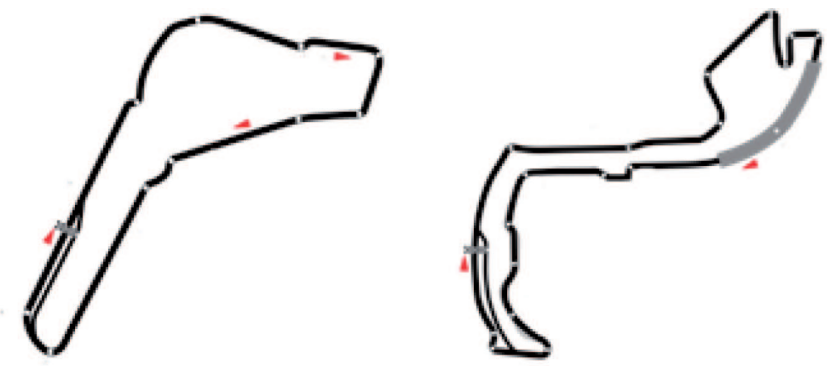

Fig. 1. Autodromo Nazionale Monza and Circuit de Monaco

In the past, the driver from the cockpit controlled the angle of attack of the wing mechanically; it was increased before entering a corner to generate higher downforce, and then reduced on the straight [2]. Two serious accidents that took place during the Grand Prix Barcelona in 1969 resulted in a strong tightening of the FIA regulations. One of the main principles of the rules, applicable right up until the year 2011, was to fix the aerodynamic device geometry, which did not allow changes in the angle of attack to be made during the race.

A racing car is a high-speed prototype, it is constantly evolving, developing, losing weight, gaining speed. The rate of development is so intense that teams introduce a new part to the car on average every 17 minutes [6]. As a consequence, the Formula One regulations are modified frequently, causing permanent discussion between designers and FIA. Engineers, competing to find innovations that match with regulations, try to outdo each other in finding clever ways of evading the rules. Each season, they implement new innovative methods of generating downforce with the purpose of achieving better results. The best ideas are copied by other teams, while the authorities have to control all technical solutions to ensure the safety of teams and spectators in case of an accident. A significant solution development in the 2010 season was the mysterious 'RW80' applied in McLaren's MP4-25 racing car. The inlet to the system was situated under the letter F of the "Vodafone" branding located at the top of the car body, which is why the system was eventually dubbed the "F-duct" by journalists.

McLaren's team pioneered a neat solution that allows the driver to control the flow over the rear wing by means of a special duct allocated inside the 
racing car. Engineers used the driver's movement as the switch, and since the driver was not considered an aerodynamical device, the system did not infringe the regulations. The air inlet is located in the front part of the racing car in the upper body between the front wheels. The conduit continues along the body, running next to the driver, and ends at an outlet to the rear wing. In the cockpit, there is a vent that is blocked by the driver's left leg, which is not in use on long straights. Consequently, the air which normally comes into the cockpit is redirected to the duct and, with the air from the gearbox, led towards rear wing's slots and disturbs the flow over the wing. Pressure changes caused by the injection of air through small outlets on the rear wing affect the wing in such a way that it enters a stalled state at high speed, reducing aerodynamic drag, and allowing the car as much as an extra $6 \mathrm{mph}$ $(9.7 \mathrm{~km} / \mathrm{h})$ on straights. Since the F-duct conduit was located inside the body which has been homologated as a whole, other teams could not see the details of this solution.

McLaren used stall to reduce the aerodynamic drag of a rear wing, which naturally occurs when the value of the angle of attack is increased. As shown in Figure 2, at low angles of attack, lift coefficient $\mathrm{C}_{l}$ rises linearly with the angle of attack, and the flow is attached over the entire edge of the profile. A survey of the airfoil aerodynamics indicates that the value of the lift generated is the result of the difference between positive pressure distribution on one side of the wing, and negative pressure distribution on the other [2]. Moreover, Figure 2 shows that the profile drag coefficient $\mathrm{C}_{d}$ increases with the angle of incidence.

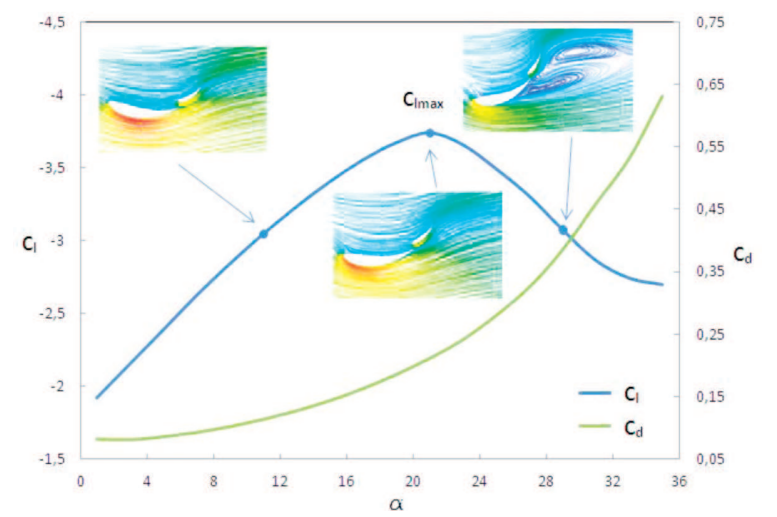

Fig. 2. Variation of lift and drag coefficient with angle of attack

Therefore, as shown in Figure 3, an increase in the angle of attack causes a drop in the pressure value on the lower edge, resulting in a rise in the pressure difference between edges. However, at a certain angle of attack, the downforce coefficient reaches its maximum value $\mathrm{C}_{\operatorname{lmax}}$ and starts decreasing 
due to flow separation on the bottom edge. The wing profile is stalled, and a higher pressure after the point of detachment occurs. Consequently, the wing works effectively only on a part of its surface, and produces less downwards lift. Flow separation creates a wake of turbulent flow behind the wing profile. The velocity in the area of detachment is low, while the pressure at the surface of the wing remains constant, close to ambient pressure.

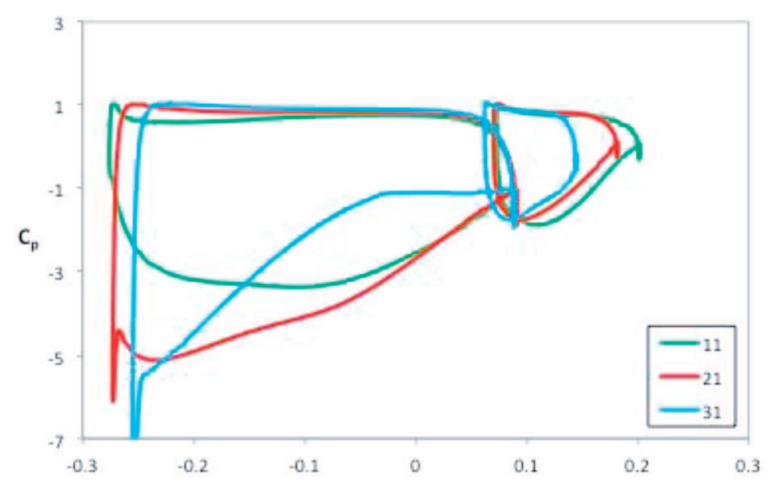

Fig. 3. Surface pressure coefficient distribution over the profile for angles of attack 11, 21 and 31 deg

Increasing the angle of attack raises the value of the profile drag coefficient, as shown in Figure 2. This increase is significant, and is caused by a rise in pressure drag due to flow separation. One may ask why does the stall of a rear wing, which is correlated with an aerodynamic drag force increase, enhance the speed of a race car on straight sections of the race track? The reason is that the aerodynamic drag also consists of the drag linked to the effects of vortices in the flow that form on the wing edges and propagate in the flow behind the wing, as shown in Figure 4.
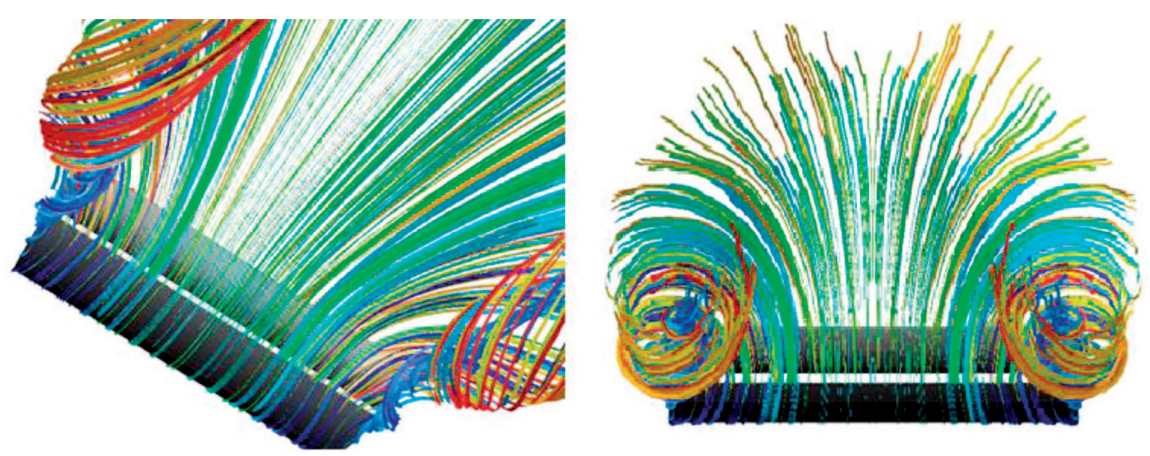

Fig. 4. Propagation of the edge vortices in the flow behind the wing

This is called the induced drag, and is an inevitable consequence of the generation of downforce by means of a finite wing span. The flow over the 
wing tends to flow from the high pressure surface towards the low pressure surface, as shown in Figure 5, leaking around the tips of the wing and creating two strong vortices. Edge vortices therefore shed from the wing side edge, changing the velocity and direction of the airflow behind the trailing edge, deflecting it downwards, and thus inducing a downwash behind the wing. The strength of the vortex is directly related to the produced lift. Therefore, the decrease in downforce caused by stall is very important because it reduces the induced drag. The analysis of the flow over the wing in two dimensions assumes that the wing is infinitely long. Therefore, such a study does not include the span dimension of the wing, and thus also does not take into account all the phenomena associated with three-dimensionality of the flow $[3,4]$.

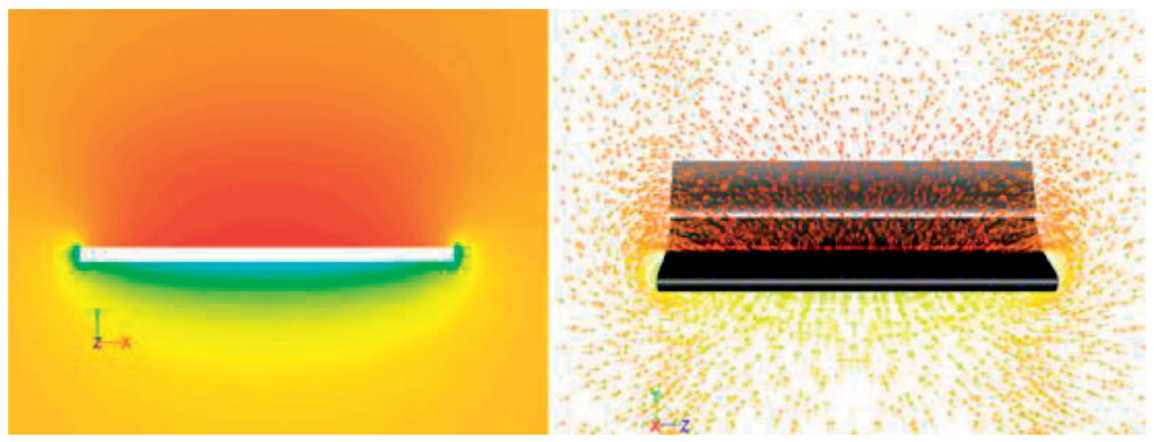

Fig. 5. Computed pressure contours and velocity vectors on the cross section along the wing span

Teams have known for a long time that stalling the rear wing drastically reduces downforce and, as a result, decreases aerodynamic drag. McLaren's engineers obtained stall by forcing separation by altering the flow over the wing via introducing an air stream from slots placed in the lower surface. Similar solutions have already been employed, e.g. flexible wings deflecting due to high speed. However, these have been forbidden after several accidents, and the rear wings became subject to static load tests. McLaren came up with the F-duct idea initially, though there have been other attempts of recreation by Sauber, Williams, and Ferrari with a changing level of success. Some systems developed by manufacturers require the driver to remove a hand from the steering wheel in order to close the vent, which has raised questions about the safety of use. During voting, most teams opted for forbidding the use of the system in the next season.

Any data describing the aerodynamic drag reduction caused by controlled flow separation are not published, so the main aim of the paper is the presentation of results of numerical investigations on these phenomena. The research was based on the position of duct outlets located on the main and secondary profile element, which was a primary geometrical parameter 
tested. Moreover, the influence of the slot air stream velocity on the strength of separation, surface pressure distribution, and the generated lift and drag forces was investigated.

\section{Simulation of controlled flow separation}

Test case description

The geometry employed in the two-dimensional simulation of the controlled flow separation on a two-element wing was the rear wing profile designed for the Formula Student race. It was a dual-element profile consisting of airfoil GOE525 as the main element, and an additional element located to achieve the greatest possible downforce. A numerical simulation was conducted for 5 models with different localisations of the slots introducing air streams in directions normal to the airfoil surface. There were three air outlets on the main profile, and two on the secondary profile element located at the bottom edge in the positions shown in the Figure 6 . The profile data were collected for two angles of attack equal to $11^{\circ}$ and $21^{\circ}$. To perform the numerical simulation, we employed the software package ANSYS $($. The grid was prepared in Gambit $®$, and the numerical analysis was conducted using Fluent $®$.

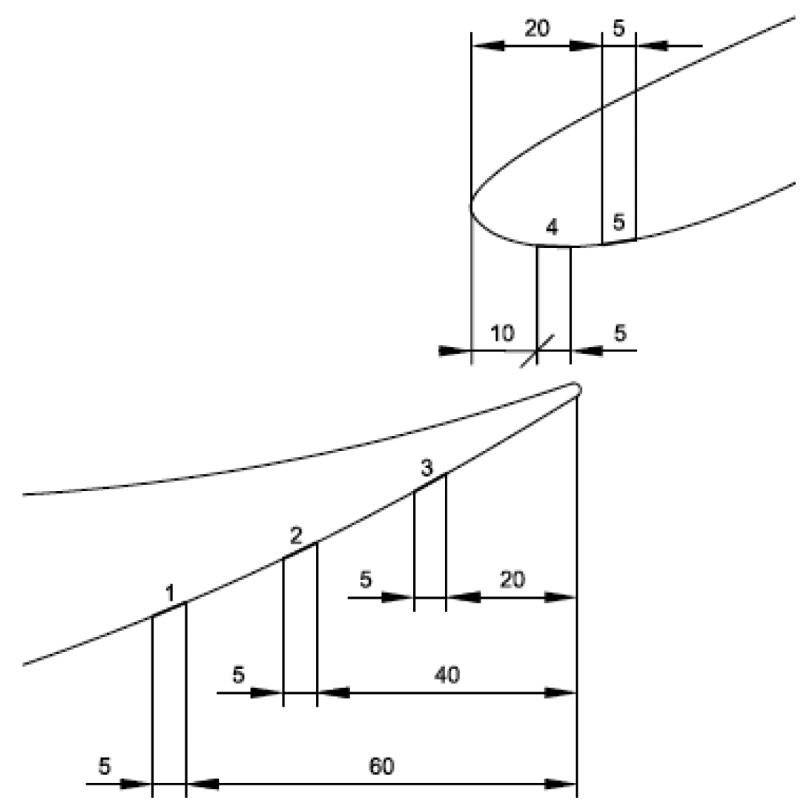

Fig. 6. Location and numbering of slots 


\section{Computational domain}

The computational domain, shown in Figure 7, was created as a rectangular wind tunnel test section, the length and a width of which were $20 \mathrm{~m}$ and $10 \mathrm{~m}$, respectively. It was divided into two areas, the inner, which formed a circle with a radius of $1.5 \mathrm{~m}$ and the outer, its complement. The centre of the inner surface was located $6 \mathrm{~m}$ from the inlet and $1 \mathrm{~m}$ from the bottom to take into consideration the additional effects due to ground proximity. The domain consisted of external boundaries: inlet, outlet, bottom, top and internal: interface, profile, and slot.

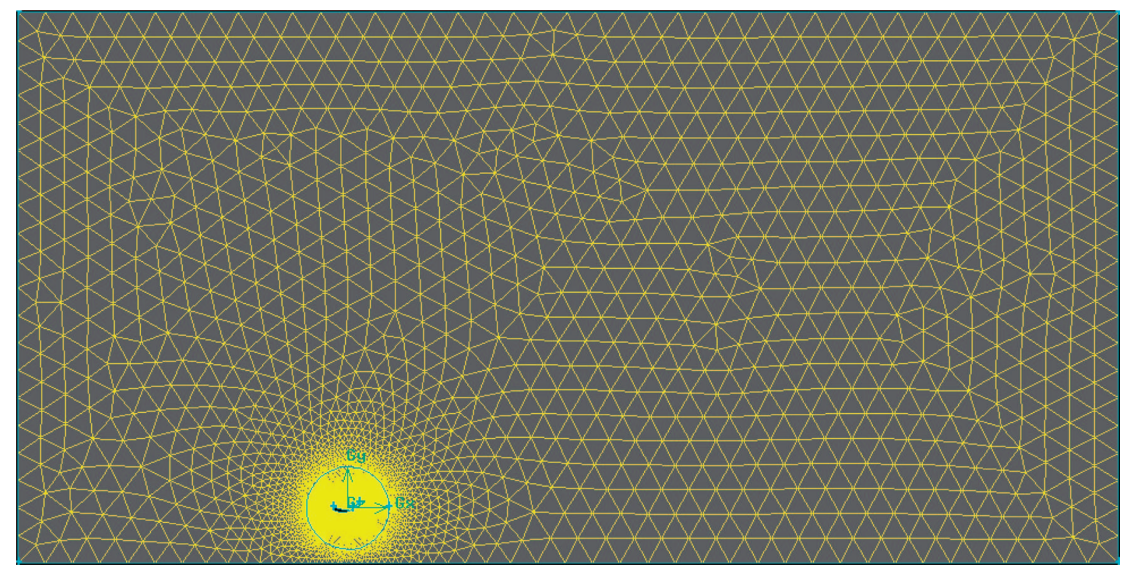

Fig. 7. Computational domain

Nodes were distributed on the profile edges as shown in Figure 8, with their interval decreasing gradually in the direction of leading and trailing edges, and in proximity of the slot. The grid comprised two main parts: the near field, which was formed of triangular elements with a successive expansion ratio 1.05 , a maximum height $50 \mathrm{~mm}$ evolving in the far field domain with a ratio of 1.25 , and $500 \mathrm{~mm}$ maximum cell height. The other part, a dense field applied to take into account the changes occurring in the velocity boundary layer, consisted of 15 layers of a rectangular near-wall grid surrounding the profile, as shown in Figure 9.

\section{Boundary conditions}

Non-slip boundary conditions were applied on the top and bottom profile edges. A constant value of the velocity normal to the boundary was applied on the inlet and in the slots. The pressure outlet boundary condition was applied in the outlet boundary. Numerical analysis was carried out for viscous fluid with Spalart-Allmaras turbulence model [5]. The velocity at the inlet was 30 


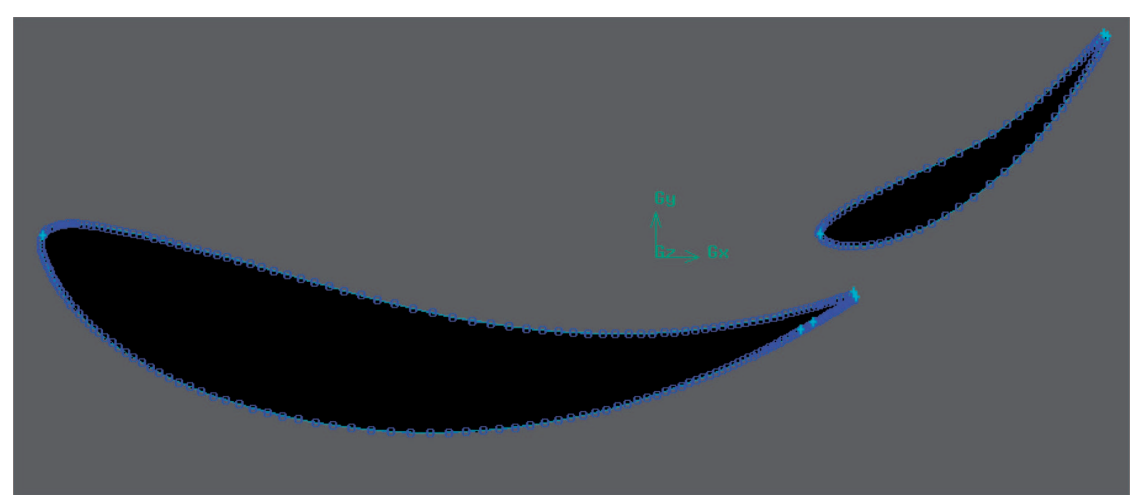

Fig. 8. Nodes distribution on the profile edges
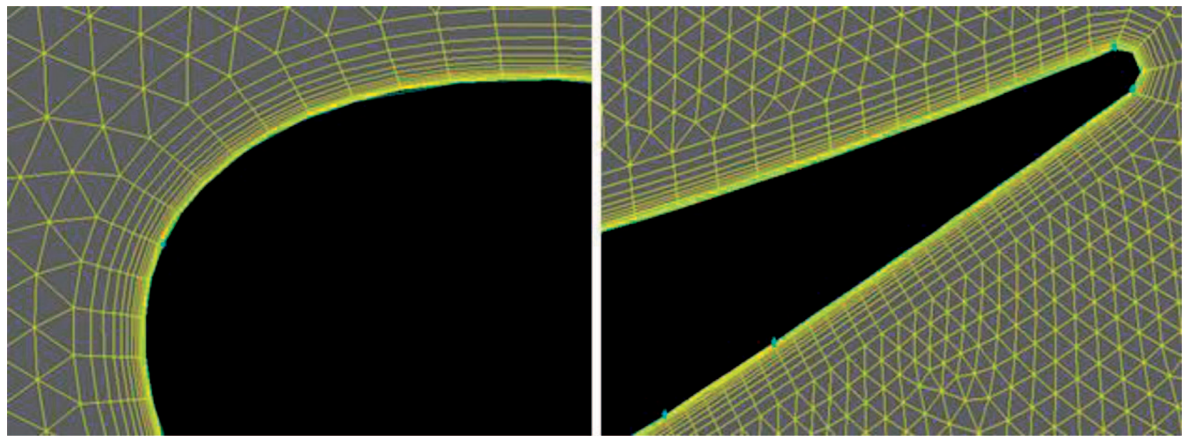

Fig. 9. Distribution of the near-wall layers

$\mathrm{m} / \mathrm{s}$, while setting the turbulent intensity and the turbulent length scale to $3 \%$ and $0.003 \mathrm{~m}$, respectively. The simulation was conducted for slot velocities of $0,5,10,15,20,25$, and $30 \mathrm{~m} / \mathrm{s}$.

\section{Results of numerical simulations}

In order to understand how the F-duct system works, the analysis and discussion of the results was divided into two parts. First, the value of the lift and drag coefficient, which varied with the velocity of the injected air stream at the outlet of the duct, was discussed based on the pressure distribution. Second, the value of induced drag was estimated, and the total drag coefficient was analysed with taking into account the influence of the additional air streams provided to flow. Additionally, the relation of the induced and profile drag was included. The aim of this research was to provide a numerical analysis of the introduction of a disturbance to the flow over the wing, which forces a controlled separation, and induces stall. The position of slots was the primary geometrical parameter investigated. 


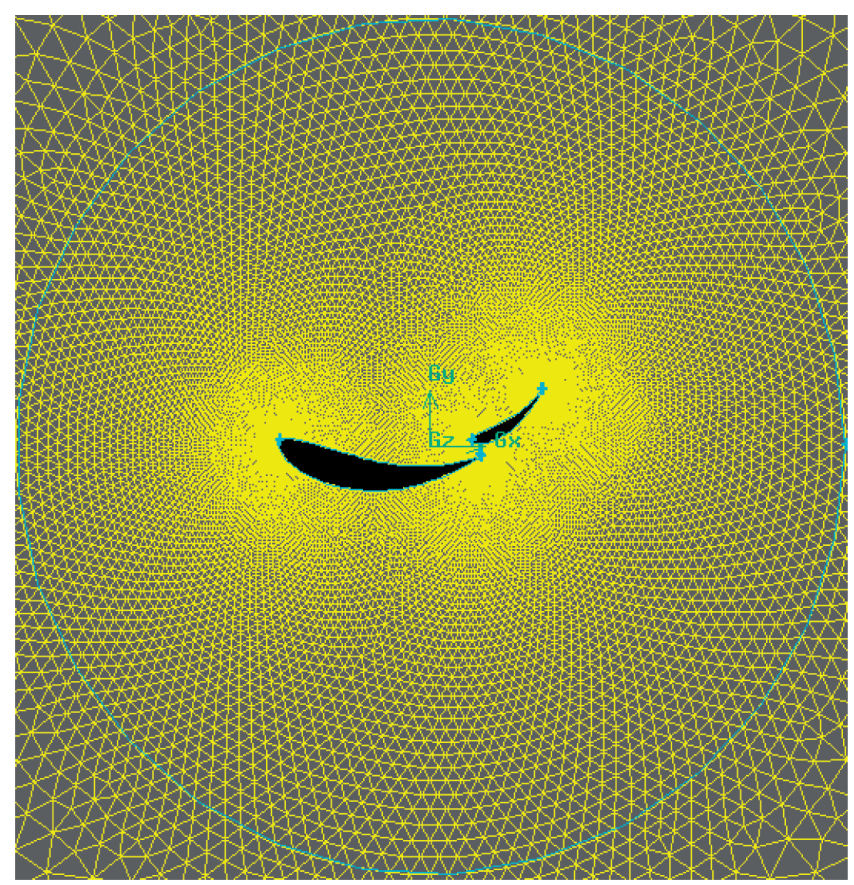

Fig. 10. Cells distribution in the near filed

\section{Lift and drag coefficient}

Figures 11-14 show the variation of the lift and profile drag coefficient versus slot air velocity for 5 models obtained for angles of attack equal to $11^{\circ}$ and $21^{\circ}$. The air jets velocity was expressed in relation to the free stream velocity over the wing profile. The collated results show that, with an increase in the velocity, a significant decrease in the value of the lift coefficient is observed. Additionally, with a growth in duct outlet velocity, one can notice a rise in profile drag coefficient.

The value of the lift coefficient for outlets located on the main profile at an $11^{\circ}$ angle of attack decreased gradually, maintaining a generally linear character. However, for the $21^{\circ}$ angle of attack at which the maximum lift coefficient was obtained, an increase in velocity at the slot located at the main wing resulted in a drop in the value of the lift coefficient, and that dependence was nonlinear. This was caused by the natural occurrence of flow separation forced by setting the airfoil at the angle of attack for which $\mathrm{C}_{\text {lmax }}$ was obtained.

For $11^{\circ}$ angle of incidence, as shown in Figure 16, there occurred velocity separation beginning from the lowest air stream slot, and with increasing flow velocity in the air stream slot the area of detachment extended and increased its intensity. Flow separation created a wake of turbulent flow behind the wing 
profile. Figure 15 shows the pressure distribution over the profile at $11^{\circ}$ angle of attack and for slot 1 activated. It can be noticed that the pressure on the lower edge of the main element increased with an increase in outlet velocity from the duct. Moreover, downstream of the air injection, the pressure grew with the slot air velocity until it reached a value close to the ambient pressure and remained constant. All this meant that the wing profile was stalled and consequently the higher pressure after the point of detachment caused an increase in pressure on the lower surface similar to the natural separation that would occur due to the increasing angle of attack. As a result, the wing worked effectively only on a part of its surface and produced less negative lift force. The pressure coefficient distribution plots also show clearly that the pressure around an additional element did not change with the variation of velocity in slots located at the main profile. Therefore, the introduction of the air stream had no effect on the flow around an additional element profile to which the flow remained attached.

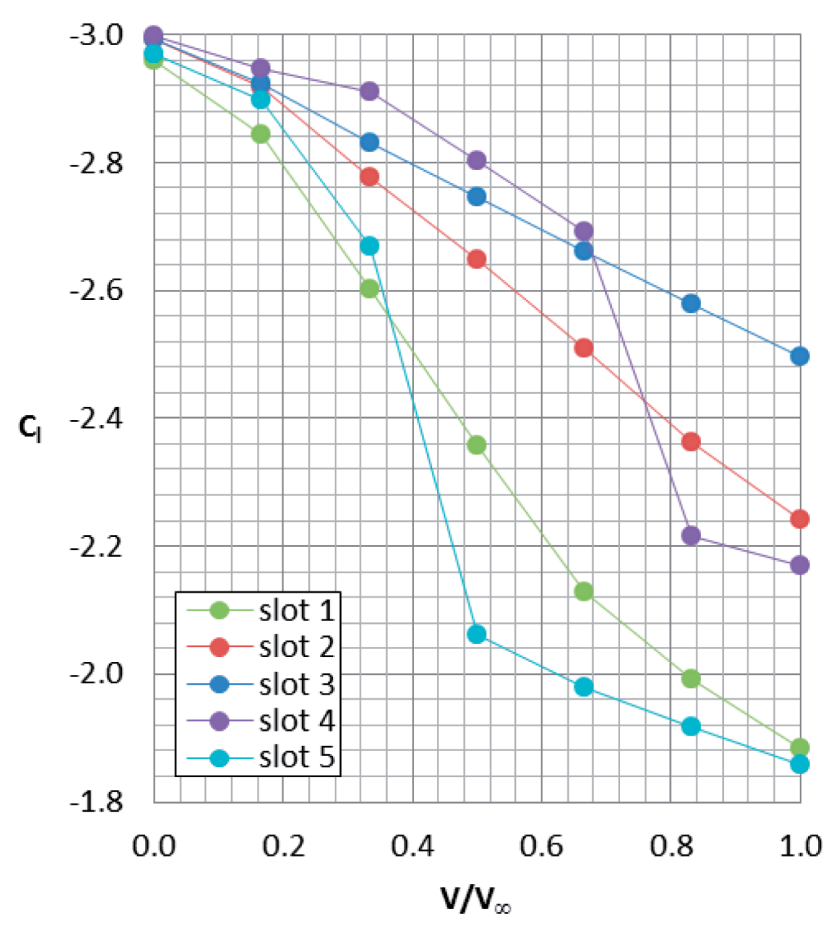

Fig. 11. Calculated lift coefficient at $11^{\circ}$ of incidence 


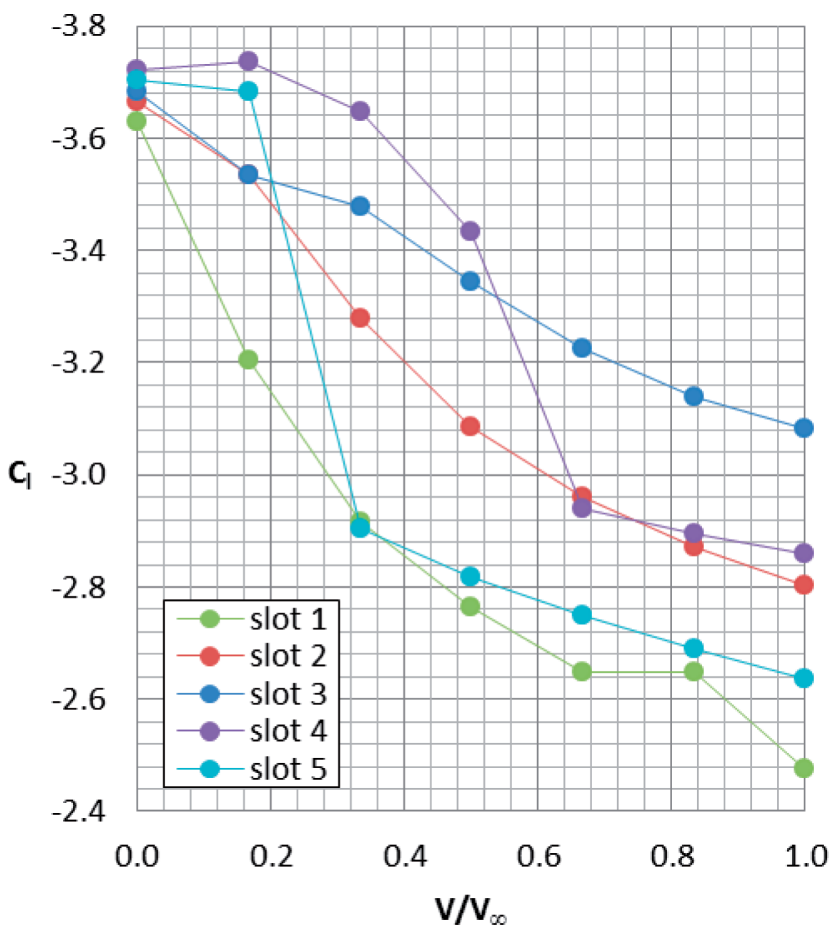

Fig. 12. Calculated lift coefficient at $21^{\circ}$ of incidence

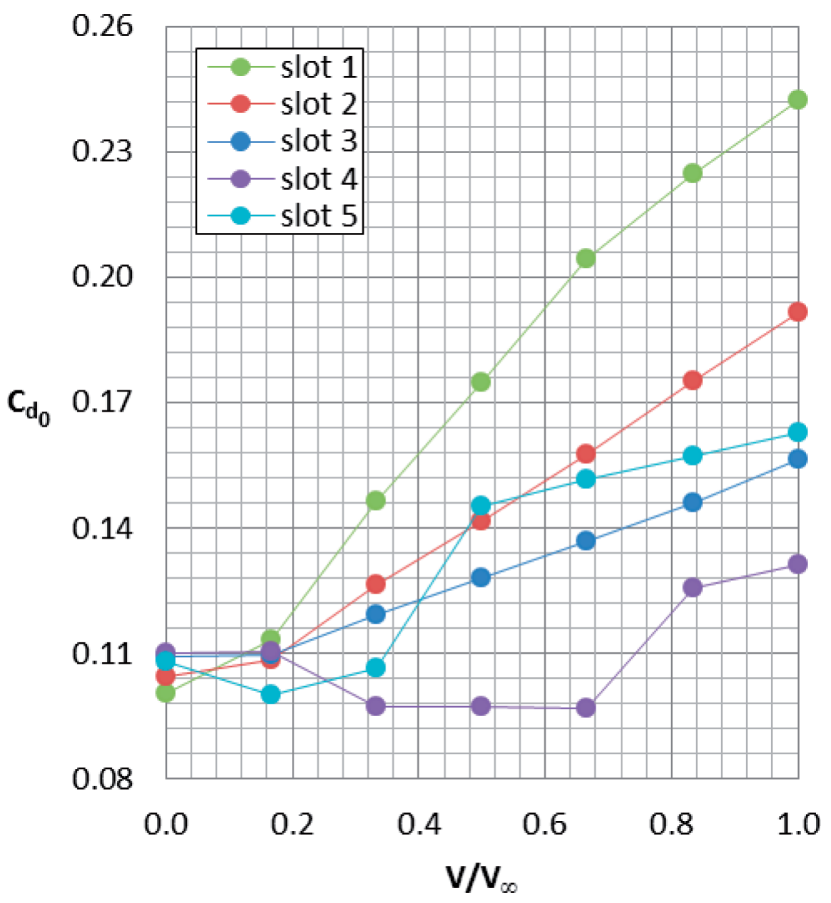

Fig. 13. Calculated drag coefficient at $11^{\circ}$ of incidence 


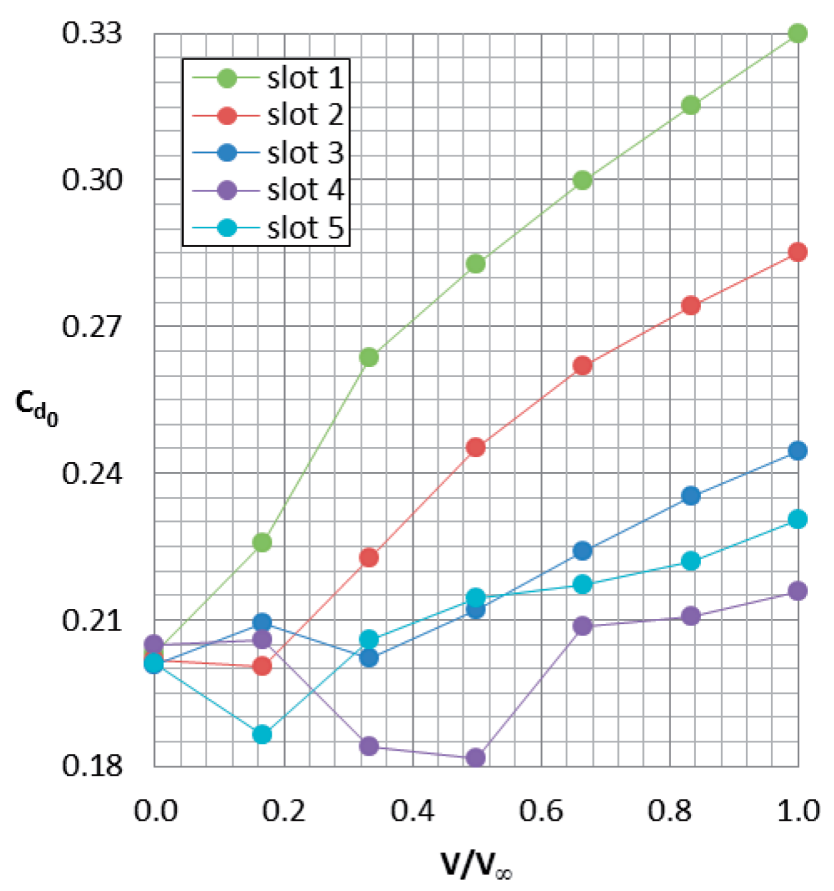

Fig. 14. Calculated drag coefficient at $21^{\circ}$ of incidence

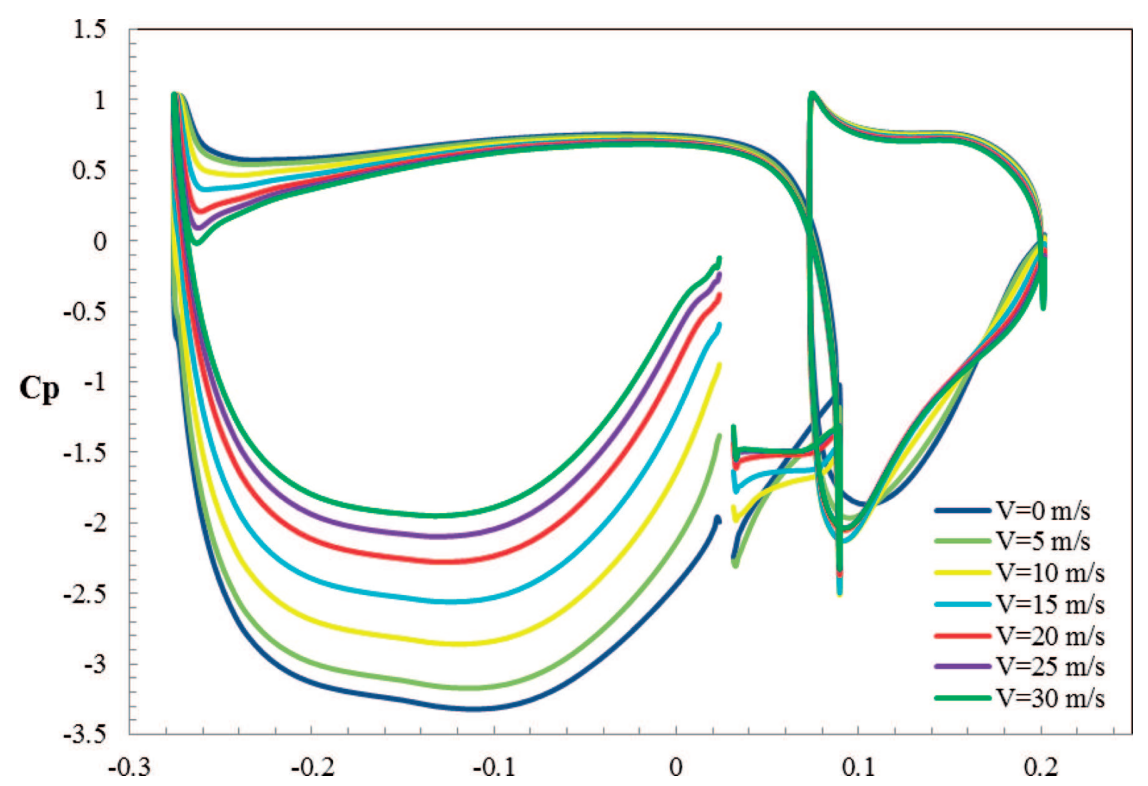

Fig. 15. Calculated surface pressure coefficient distribution over the wing at $11^{\circ}$ of incidence with active slot 1 


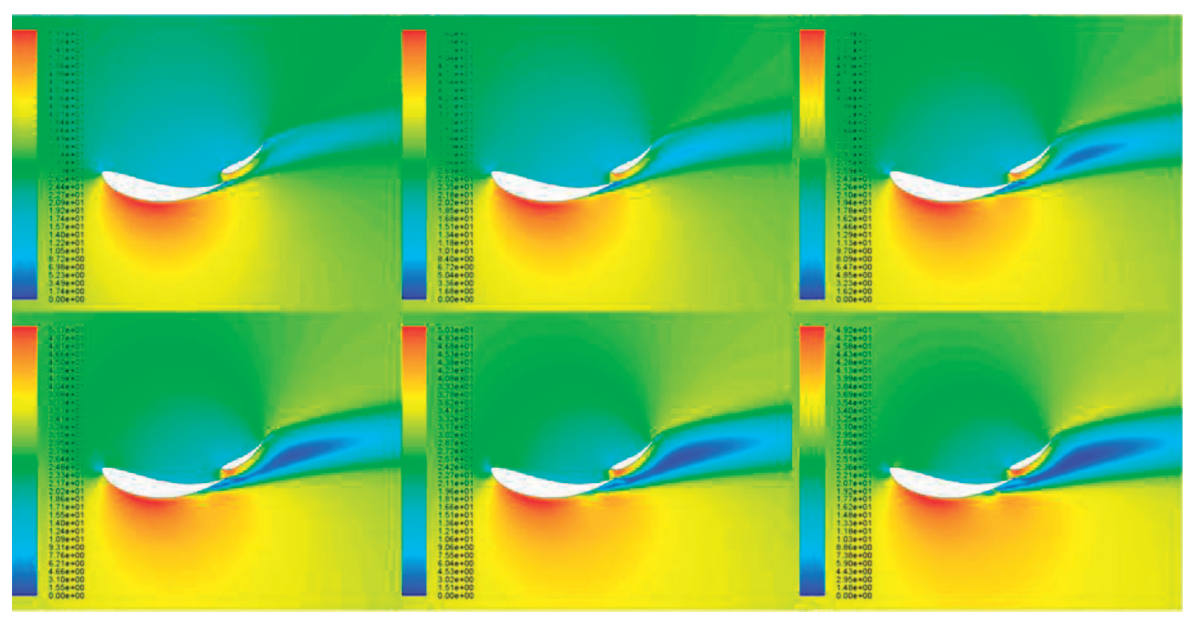

Fig. 16. Computed contours of air velocity around the wing profile at $11^{\circ}$ of incidence for slot 1 active

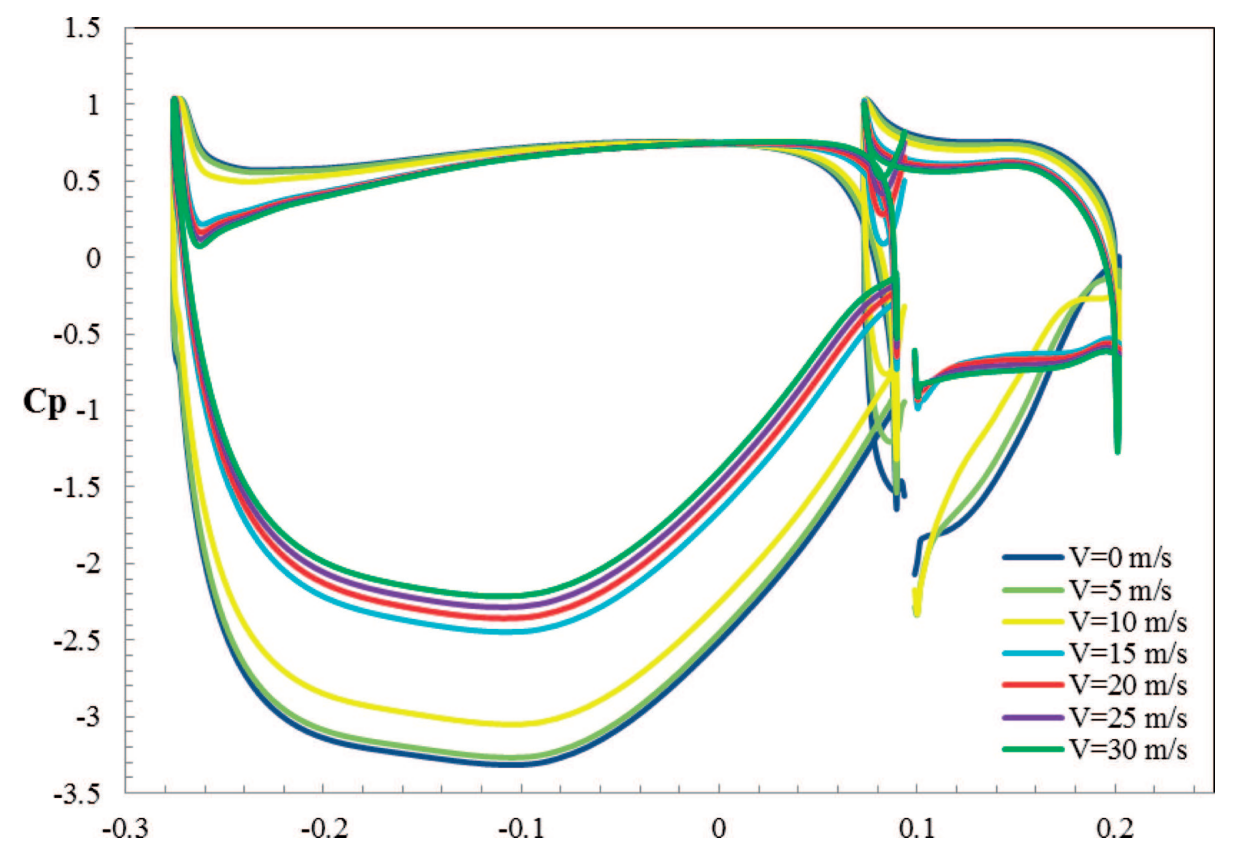

Fig. 17. Calculated surface pressure coefficient distribution over the wing at $11^{\circ}$ of incidence for slot 5 active 


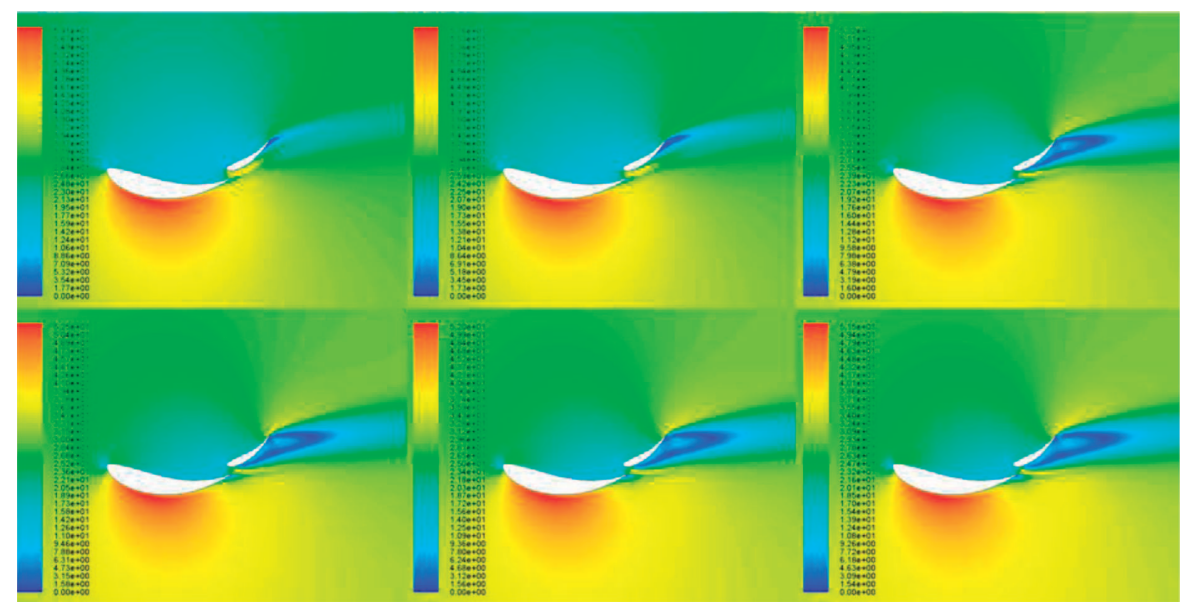

Fig. 18. Computed contours of air velocity around the wing profile at $11^{\circ}$ of incidence for slot 5 active

For both angles of attack, the air injected through slots located on the main profile increased the drag coefficient significantly due to the velocity of the air flow from the outlet altering the flow over the wing, as shown in Figure 13 and 14. This increase is associated with the pressure drag produced in the area of separation. Therefore, for both angles of attack, the largest drag and the greatest decrease in lift force was obtained for slot 1 , because it was located closer to the leading edge and the length of the section where separation occurs was the greatest one.

The curves of downforce coefficient for the air jets located on the additional profile, shown in Figures 11 and 12, are characterized by a rapid decrease after a certain value of the duct outlet velocity was reached, which was unique for each case. This velocity was related to the occurrence of flow separation on the secondary element. Figure 17 shows the pressure distribution over the profile for slot 5 at $11^{\circ}$ of incidence. It can be noticed that the pressure on the lower edge of the main element increases with the slot air velocity, but this rise has initiated from the velocity value at which separation occurs and causes stall. For inlets situated on the flap, this effect does not take place for the low air slot velocity, which is in contrast to slots located at the main element where separation occurs from the onset. The stall on the additional element, as show in Figure 18, causes a small separation at the trailing edge. For both incidences, the greatest decrease in lift force is observed for slot 5 .

For slots located on the additional profile, the drag coefficient behaves differently to the previous cases, as shown in Figure 13 and 14. For low velocity decreases, the value of the coefficient for slot 5 at both angles of attack considered remains almost constant, but it is followed by a gradual 
rise with an increase in the additional air stream velocity. The increase of drag is associated with a sharp drop in value of the downforce coefficient caused by a stall. The curves of drag coefficient for slot 4 behave similarly. However, initially there is a slight growth in value observed.

\section{Induced drag coefficient}

The total drag of a finite wing consists of the pressure and the viscous drag for a two-dimensional wing profile and additionally of wing tip vortexinduced drag. Therefore, all of these components were included. The induced drag values depend on the intensity of the vortices, which are determined by the value of downforce produced, and are therefore estimated by the approximate formula [1]:

$$
C_{d_{i}}=\frac{C_{l}^{2}}{\pi \lambda}
$$

where $\lambda$ is a wing aspect ratio. This value, considered for a wing with end plates, was determined by applying the formula suggested by Hoerner [1]:

$$
\lambda=\frac{b}{c\left(1+1.9 \frac{h}{b}\right)}
$$

where the wing span $\mathrm{b}$ and the chord $\mathrm{c}$ were $1 \mathrm{~m}$ and $0.5 \mathrm{~m}$ respectively, and the edge plate height $h$ was $1 \mathrm{~m}$.

The formula describing the induced drag is derived for the attached flow and is not fully valid for the separated flow case. Due to that fact, the following consideration shows only the aproximate drag reduction values.

The value of the total drag coefficient varied with the slot air velocity for both angles of attack, as shown in Figure 19 and 20. As it was previously done, the jet air velocity, was expressed in relation to the free stream velocity. Since the induced drag coefficient depended on the values ??of the downforce generated by the wing, and other parameters remained constant, the characteristic was exactly the same. The lowest drag for both angles of attack was obtained for slot 1 located on the main profile, and for slot 5 , which was situated on the flap.

The ratio of the induced drag to the profile drag varied with slot air velocity for both angles of attack. To show the scale of the induced drag, this ratio is shown in Figures 21 and 22. One can notice that the value of the induced drag that occurs in three-dimensional flow analysis is much greater than the profile drag caused by pressure and shear stresses. Consequently, the downforce on which the induced drag mainly depends causes a significant drag penalty. 


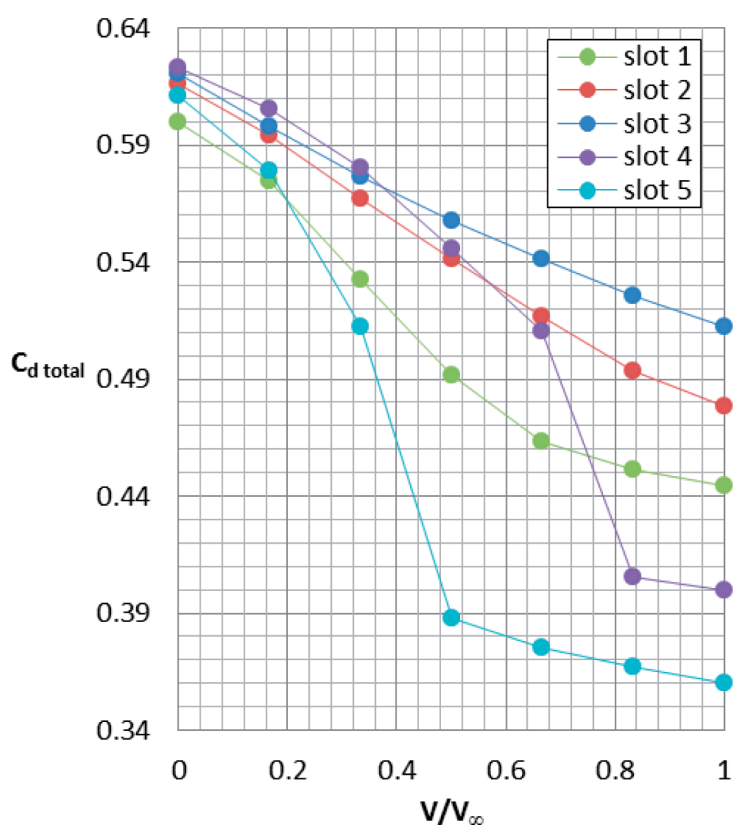

Fig. 19. Estimated total drag coefficient at $11^{\circ}$ of incidence and different slots active

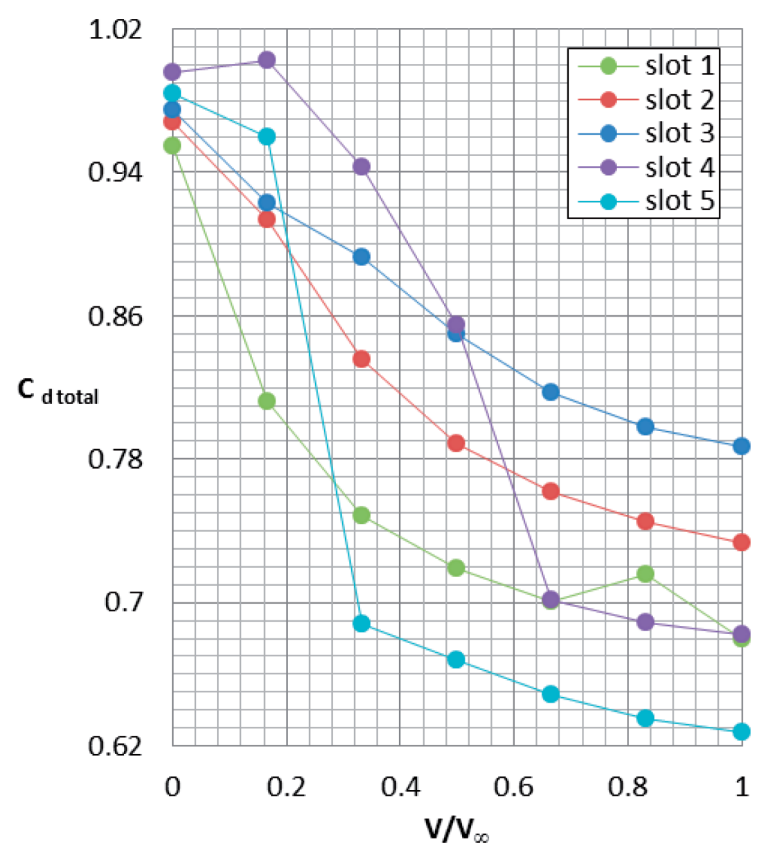

Fig. 20. Estimated total drag coefficient at $21^{\circ}$ of incidence and different slots active 


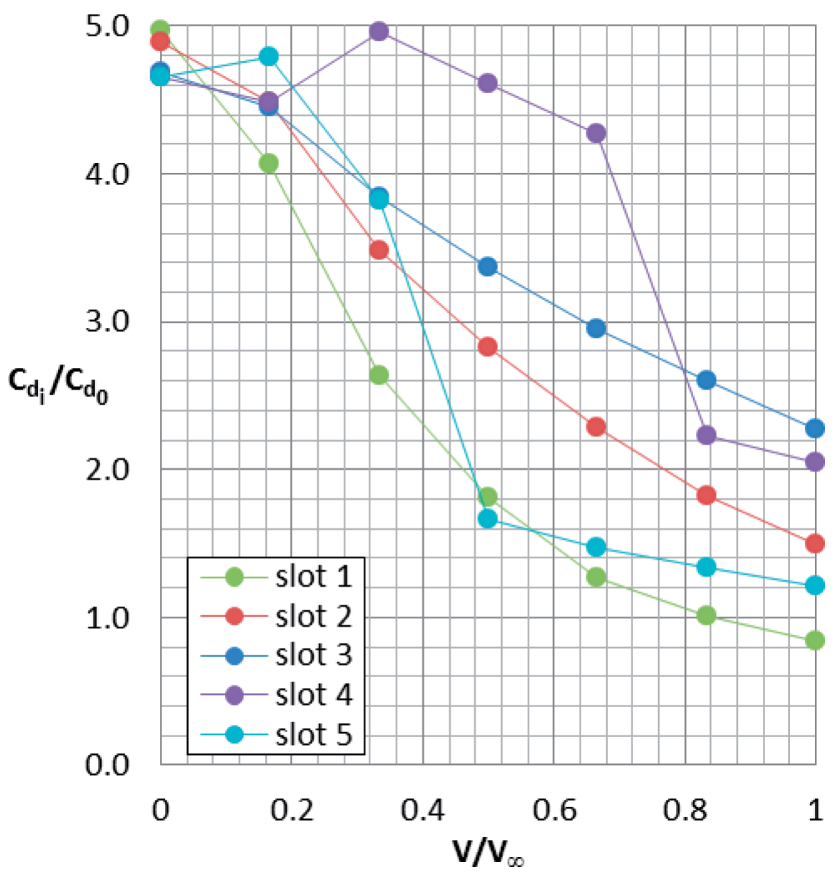

Fig. 21. Ratio of estimated induced drag values to calculated profile drag values at $11^{\circ}$ of incidence

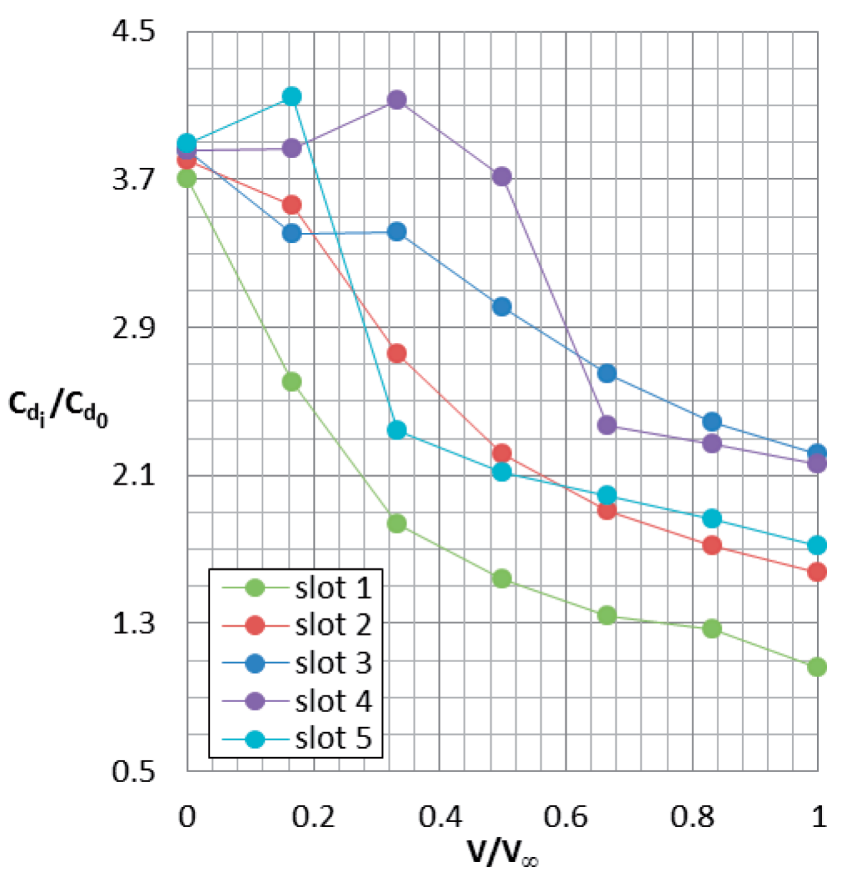

Fig. 22. Ratio of estimated induced drag values to calculated profile drag values at $21^{\circ}$ of incidence 


\section{Conclusion}

The numerical simulation was conducted for two-dimensional model of a two-element wing profile, including slots, that was designed for the Formula Student race. The investigation was conducted for 5 different slot locations with variation of its air outlet velocity at two incidences equal to $11^{\circ}$ and $21^{\circ}$. Firstly, collated results confirmed that forcing separation through altering the flow over the wing by introducing the air stream from slots affects the wing in such a way that it enters a stalled state. Furthermore, two different flow separation structures have been recognised. Injections of air through slots located on the main airfoil element only cause separation on the main element, leaving the additional element with attached flow. This is unlikely to what is done by slots located at the additional airfoil element, which generate separation on both elements. In the 2D analysis, profile stall conditions were always correlated with an increase in the profile drag. Taking into account additional three-dimensional effects on a low aspect wing used in cars, stall conditions were accomplished by the reduction of total aerodynamic drag that were strongly affected by induced drag of vortical structures at the wing tips. Finally, if the flow over the wing is stalled, the result is a huge drop in the downforce coefficient resulting in total net drag reduction, even if the profile drag increases. This is the reason for major benefits in terms of the top speed of a racing car. It should be noted, however, that stalling the flap is more beneficial than the main wing stall. The investigation has shown that the optimal position of the duct outlet is slot 5 , for which forced flow separation occurs at the lowest slot outlet air velocity.

Manuscript received by Editorial Board, May 18, 2012;

final version, March 12, 2013.

\section{REFERENCES}

[1] Katz J.: Race Car Aerodynamics. Designing for Speed. 2nd. ed. Cambridge, Bentley Publishers, 2006

[2] Piechna J.: Podstawy aerodynamiki pojazdów. Warszawa, Wydawnictwo Komunikacji i Łączności, 2000.

[3] Abbott I. H., von Doenhoff A. E.: Theory of Wing Sections. New York, Dover Publications, 1959.

[4] Anderson J. J. D.: Fundamentals of Aerodynamics. 3rd. ed. New York, McGraw-Hill, 2001.

[5] Went J. F.: Computational Fluid Dynamics an Introduction. 3rd. ed. Springer, 2009.

[6] McLaren. http://www.mclaren.com/formula1/mp4-27. Internet web-site, accessed on $20 / 01 / 2013$. 
Numeryczne badanie sterowanego oderwania przepływu spowodowanego przez dodatkowe strumienie powietrza $\mathrm{z}$ dysz umieszczonych na skrzydle

\section{Streszczenie}

W artykule przedstawiono wyniki badań numerycznych zjawiska sterowanego oderwania przepływu na płacie dociskowym praktycznie wykorzystywanym w wyścigach Formuły 1 przez urządzenie o nazwie F-duct. Oderwanie przepływu zostało spowodowane wprowadzeniem zaburzenia poprzez strumień powietrza ze szczeliny, co doprowadziło do zmniejszenia całkowitego oporu aerodynamicznego płata dociskowego. Pozycje szczeliny i prędkość powietrza z nich wyrzucanego były głównymi parametrami kontrolującymi oderwanie przepływu. Głównym przedmiotem badań były: struktura przepływu, rozkłady ciśnienia na powierzchni profilu oraz generowane siły nośna i oporu. Podczas badań zostały rozpoznane dwie różne struktury oderwania przepływu. Zazwyczaj oderwanie przepływu na płacie związane jest ze wzrostem oporu profilowego. Jednak w przypadku trójwymiarowym dla płata o skończonej rozpiętości występuje dodatkowy składnik oporu ciśnieniowego spowodowany pojawieniem się wirów krawędziowych. Opór ten jest proporcjonalny do współczynnika siły docisku. Eksperyment pokazał, że oderwanie przepływu występujące na płacie dociskowym zwiększa opór profilowy, ale jednocześnie zmniejszając opór indukowany co w konsekwencji prowadzi do zmniejszenia całkowitego oporu aerodynamicznego. 